\title{
A New Thioalkalivibrio sp. Strain Isolated from Petroleum-Contaminated Brackish Estuary Sediments: A New Candidate for Bio-Based Application for Sulfide Oxidation in Halo-Alkaline Conditions
}

\author{
Simone Becarelli ${ }^{1}{ }^{\circ}$, Salvatore La China ${ }^{2}$, Alla Lapidus ${ }^{3}{ }^{\circledR}$, Andrey Prijibelski $^{3}$, \\ Dmitrii Polev ${ }^{4}$ (D) Giulio Petroni ${ }^{1}$ and Simona Di Gregorio ${ }^{1, * \mathbb{D}}$ \\ 1 Department of Biology, University of Pisa, Via Luca Ghini 13, 56127 Pisa, Italy; \\ simone.becarelli@biologia.unipi.it (S.B.); giulio.petroni@unipi.it (G.P.) \\ 2 Department of Life Sciences, University of Modena and Reggio Emilia, Via G. Amendola 2, Pad. Besta, \\ 42122 Reggio Emilia, Italy; salvatore.lachina@unimore.it \\ 3 Center for Algorithmic Biotechnology, Institute of Translational Biomedicine, St. Petersburg State University, \\ St. Petersburg 199034, Russia; a.lapidus@spbu.ru (A.L.); andrewprzh@gmail.com (A.P.) \\ 4 Centre Biobank, Research Park, St. Petersburg State University, St. Petersburg 198504, Russia; \\ brantoza@gmail.com \\ * Correspondence: simona.digregoriol@unipi.it
}

Received: 16 April 2020; Accepted: 11 May 2020; Published: 13 May 2020

\begin{abstract}
A new halo-alkaline sulfur-oxidising bacterial strain was isolated from brackish estuary sediments contaminated by total petroleum hydrocarbon. The isolate was classified as a new strain of Thioalkalivibrio sulfidiphilus sp., showing a higher capability of adaptation to $\mathrm{pH}$ and a higher optimal sodium concentration for growth, when compared to Thioalkalivibrio sulfidiphilus sp. HL-EbGr7, type strain of the species. The strain was capable to grow in saline concentrations up to $1.5 \mathrm{M} \mathrm{Na}^{+}$ and $\mathrm{pH}$ up to 10 . The genome of the new isolate was sequenced and annotated. The comparison with the genome of Thioalkalivibrio sulfidiphilus sp. HL-EbGr7 showed a duplication of an operon encoding for a putative primary sodium extruding pump and the presence of a sodium/proton antiporter with optimal efficiency at halo-alkaline conditions. The new strain was able to oxidize sulfide at halo-alkaline conditions at the rate of $1 \mathrm{mmol} / \mathrm{mg}-\mathrm{N} / \mathrm{h}$, suitable for industrial applications dedicated to the recovery of alkaline scrubber for $\mathrm{H}_{2} \mathrm{~S}$ emission absorption and abatement.
\end{abstract}

Keywords: Thioalkalivibrio sulfidiphilus sp.; sulfide oxidation; sodium extruding pump; sodium/proton antiporter; Dissimilatory Sulfite Reductase complex; Hetero Disulfide Reductase complex; alkaline sodium/proton antiporter

\section{Introduction}

In strongly antropized environments, contaminated matrices should be evaluated also as source of microorganisms of interest capable of strategies of adaptation to the environment that might be similar to the one that the "properly said" extremophiles adopt to survive to extreme conditions. Historical contaminations are associated to changes in the chemical and/or physical characteristics of most of the ecological niches afflicted by the contamination, with possible alteration of the natural $\mathrm{pH}$, depletion of waters, and other diverse effects. For these reasons, contaminated matrices can be a source of microbial candidates with interesting features that might find applications in the abatement of contaminants. In fact, contaminated matrices have already been a source of isolation of interesting new microbial strains, showing metabolic features exploitable for diverse biotechnological applications [1-4]. 
In this study, a new strain of the haloalkaliphilic genus Thioalkalivibrio was isolated from brackish estuary sediments, contaminated by petroleum-derived hydrocarbons. Most of the strains of the genus Thioalkalivibrio have been extensively and nearly exclusively described as colonising the microflora of soda lakes [5,6], characterized by double extreme conditions, high $\mathrm{pH}$ and salinity. However, the presence of the genus Thioalkalivibrio in brackish sediments has also been recorded by the screening of clone libraries from metagenomic extracts or deep sequencing of metagenomes from different sampling sites [7-11]. In this case, the information was limited to the genomic data acquisition. From these environments, any strains were actually isolated, cultivated and characterized.

The Thioalkalivibro genus grows chemolithoautotrophically using hydrogen sulfide $\left(\mathrm{H}_{2} \mathrm{~S}\right)$ as the electron donor. The genus is of interest for the bio-based industrial sector and several Thioalkalivibrio sp. strains found application in bio-based processes for the oxidation of $\mathrm{H}_{2} \mathrm{~S}$ emissions and the recycling of adsorbing alkaline scrubbers, characterized by a $\mathrm{pH}$ up to 10 and high sodium concentration [12-14]. $\mathrm{H}_{2} \mathrm{~S}$ is a highly toxic gas, produced as a waste product in several industrial processes, such as leather tanning and paper manufacturing, energy production by petroleum refining, biogas. and geothermal sources [15]. Classic physical-chemical treatments for $\mathrm{H}_{2} \mathrm{~S}$ removal, like the Claus-Scott and the Stretford processes, are demanding in terms of energy consumption and/or chemicals [15].

The scope of this work was the description of a new bacterial strain that is capable of oxidizing $\mathrm{H}_{2} \mathrm{~S}$ in halo-alkaline conditions ( $\mathrm{pH}=10$ and sodium concentration between 0.6 and $1 \mathrm{M}$ ), finding applications in the development of processes dedicated to the control of $\mathrm{H}_{2} \mathrm{~S}$ emissions. The new strain, isolated from brakish and neutral sediments, might update the description of the genus Thioalkalivibrio, up to now described as colonising dual extreme environments with both extremely high $\mathrm{pH}$ and $\mathrm{Na}^{+}$ concentration, and might also update the microbial resources recoverable from the environment for the abatement of $\mathrm{H}_{2} \mathrm{~S}$. The genome of the strain was sequenced and the genes, responsible for $\mathrm{H}_{2} \mathrm{~S}$ oxidation and homeostasis in halo-alkaline growing conditions, were annotated.

\section{Materials and Methods}

\subsection{Total Petroleum Hydrocarbon Quantification in Sediments}

Sediment samples were dried for $2 \mathrm{~h}$ at $105 \pm 1{ }^{\circ} \mathrm{C}$ in an oven. A total of $10 \mathrm{~g}$ (dry weight) were put in $125 \mathrm{~mL}$ glass-stoppered flasks and extracted in $40 \mathrm{~mL}$ acetone/n-heptane (1:1), containing $15 \mu \mathrm{L} / \mathrm{L}$ dodecane and $15 \mathrm{mg} / \mathrm{L}$ tetracontane as internal standards. The samples were extracted by shaking on a rotary shaker at $200 \mathrm{rpm}$ for one hour, at room temperature. Extracts were decanted by gravity and the supernatants were hand shaken in a separating funnel containing $100 \mathrm{~mL}$ of water to remove acetone. The step was repeated twice. The residual organic layer (containing n-heptane, internal standards, and total petroleum hydrocarbons, TPHs) was cleaned up by purification on pre-washed Florisil ${ }^{\circledR}$ columns, mesh 60 , and dewatered with anhydrous sodium sulfate. A volume of $1 \mu \mathrm{L}$ of extract was injected in a gas chromatograph (GC; Trace 1300, Thermo Fisher, Milano, Italy), equipped with a flame ionization detector (FID) and a $12 \mathrm{~m}$, DB5.625 column with $0.25 \mathrm{~mm}$ inner diameter (J\&W Scientific, Folsom, CA, USA). The GC running conditions were as follows: the oven temperature was programmed as $5 \mathrm{~min}$ at $50{ }^{\circ} \mathrm{C}$, ramp to $300{ }^{\circ} \mathrm{C}$ at $10{ }^{\circ} \mathrm{C} / \mathrm{min}, 300{ }^{\circ} \mathrm{C}$ for $12 \mathrm{~min}$; the FID was maintained at $325^{\circ} \mathrm{C}$. Chromatograms were recorded with Chrom-card data system (Thermo Fisher, Milano, Italy). External calibration was performed using mineral oil A + mineral oil B standards (Merck, Milano, Italy), in n-heptane, containing $15 \mu \mathrm{L} / \mathrm{L}$ dodecane and $15 \mathrm{mg} / \mathrm{L}$ tetracontane, at concentrations ranging from 100 to $10,000 \mathrm{mg} / \mathrm{L}$. Area integration was performed on blank subtracted spectra, from dodecane retention time to tetracontane retention time, according to UNI EN 16703.

\subsection{Isolation of Thioalkalivibrio sp. $10 f s 10$}

The sediments, contaminated by total petroleum hydrocarbons $(3576 \mathrm{mg} / \mathrm{Kg} \mathrm{dw} / \mathrm{dw}$ ), were characterized by a neutral $\mathrm{pH}(\mathrm{pH}=7.2)$, chlorine and sodium concentrations of 0.45 and $0.51 \mathrm{M}$ respectively. The enrichment of halo-alkaliphilic bacterial strains was performed in the DSMZ 
(Deutsche Sammlung von Mikroorganismen und Zellkulturen) $\mathrm{n}^{\circ} 925$ added with a trace element solution $(2 \mathrm{~mL} / \mathrm{L}), \mathrm{MgCl}_{2}(0.5 \mathrm{mM}), \mathrm{KNO}_{3}(5 \mathrm{mM})$, and $\mathrm{Na}_{2} \mathrm{~S}_{2} \mathrm{O}_{3}(40 \mathrm{mM})$ by incubating $1 \mathrm{~g}$ of sediments in $250 \mathrm{~mL}$ of the 1:2 diluted DSMZ $\mathrm{n}^{\circ} 925$ medium for one month at $28 \pm 1{ }^{\circ} \mathrm{C}$ on an orbital shaker at $250 \mathrm{rpm}$ in the dark. A sub-culturing passage was performed inoculating the bacterial suspension into full strength DSMZ $\mathrm{n}^{\circ} 925(5 \% \mathrm{v} / \mathrm{v})$ and, after two months of incubation, serial dilutions of the enrichment suspension were plated on agarized DSMZ n 925 medium. A single bacterial morphotype at visual inspection was identified. A total of ten different colonies with the same morphotype were analysed by amplified ribosomal DNA restriction analysis (ARDRA) [16] and repetitive sequence-based PCR (REP-PCR) [17,18]. The ARDRA analysis was performed digesting the amplification products with Sau 3A, Alu I e Hae III restriction enzymes. All analyses were performed at least twice for each isolate. A single operational taxonomic unit (OTU), 10fs10, was recovered.

\subsection{Thioalkalivibrio sp. $10 f$ s10 Genome Sequencing}

Thioalkalivibrio sp. $10 \mathrm{fs} 10$ genomic DNA was extracted by GenElute ${ }^{\mathrm{TM}}$ Bacterial Genomic DNA, following producer's instructions. DNA quantification was performed using Qubit ${ }^{\circledR} 3.0$ (Invitrogen, Thermo Fisher Life Technologies, Milan, Italy) following producer's instructions. Thioalkalivibrio sp. $10 \mathrm{fs} 10$ genome was sequenced in St. Petersburg state University, St. Petersburg (Russia) (for more details see Supplementary Materials and Methods). Genome assembly and annotation project are available at IMG, under IMG submission ID 183849.

\subsection{Taxonomic Characterisation of the Thioalkalivibrio sp. $10 f_{s} 10$}

The full-length gene coding for the 16S rRNA of Thioalkalivibrio sp. $10 \mathrm{fs} 10$ isolate was extracted from the draft genome. The sequences of the genes coding for the 16S rRNA of 77 different Thioalkalivibrio sp. strains were downloaded from Silva SSU database and from Joint Genome Institute (JGI, Berkeley, CA, USA) using IMG. All sequences were aligned using MUltiple Sequence Comparison by Long-Expectation (MUSCLE) algorithm [19] and trimmed to match the length of the shortest deposited sequence (1374 nucleotides). Maximum likelihood tree was computed using the Tamura-Nei DNA evolutionary model [20] (for more details see Supplementary Materials and Methods). The accuracy of the calculated tree was assessed by bootstrapping 1000 replicates.

\subsection{Maximum Likelihood Tree Based on Multi-Locus Sequence (MLS) Analysis}

Maximum Likelihood MLS tree was computed using concatenated amino acid sequences of ClpA-DnaJ-GyrA-RpoH-RpoS-SecF proteins, codified by respective housekeeping genes obtained from genomic annotation of Thioalkalivibrio sp. $10 \mathrm{fs} 10$ and from available complete genomes of other Thioalkalivibrio spp. on IMG The corresponding sequences of amino acids were aligned with MUSCLE algorithm [19] and concatenated in the reported order. Maximum likelihood tree was computed using a method based on the Whelan and Goldman + Freq. model [21] (for more details see Supplementary Materials and Methods).

\subsection{Classification of Thioalkalivibrio sp. $10 f s 10$ by ANI-BBH, dDDH, and Genome Taxonomy Database}

Average Nucleotide Identity was performed using Genome comparison tools available on IMG/M platform. The Average nucleotide identity (ANI) was based on Bidirectional Best Hits (BBH) with a CDS identity cut off value of 70\% [22]. Digital DNA-DNA Hybridisation (dDDH) was performed using Genome to Genome Distance Calculator (GGDC) v. 2.0 [23] available on http://ggdc.dsmz.de, using an algorithm based on "distance 2" calculation. This tool tolerates up to $80 \%$ genome deletion to achieve a resolution up to strain level [24]. MSA analysis was performed by Genome Taxonomy Database Toolkit (GTDB-Tk) tool starting from Thioalkalivibrio sp. $10 \mathrm{fs} 10 \mathrm{draft}$ genome. All 120 reference housekeeping genes used by Genome Taxonomy Database (https:/gtdb.ecogenomic.org/) classification were identified, translated into amino acid sequences, concatenated, aligned and masked to reduce the full amino acid sequence length from 41,155 to 5035 aa. A total of 30 reduced and concatenated amino 
acid sequences out of 17,413 entries of the Genome Taxonomy Database (release 86) were selected: 24 available strains previously classified as belonging to the genus Thioalkalivibrio and 6 out-groups identical to those used to compute the Phylogenetic and ML trees. Those sequences, plus queries $10 \mathrm{fs} 10$ and ALJ17 sequences were used to construct a Maximum likelihood tree. Maximum likelihood tree was computed using a method based on the Whelan and Goldman + Freq. model [21] (for more details see Supplementary Materials and methods).

\subsection{Thioalkalivibrio sp. $10 f s 10$ Growth in Halo-Alkaline Conditions}

$\mathrm{Na}^{+}$dependent growth tests were performed in DSMZ $\mathrm{n}^{\circ} 925$ medium added with the previously described trace element solution and increasing $\mathrm{Na}^{+}$concentration amended as $\mathrm{NaCl}$, from $642 \mathrm{mM}$, up to $1500 \mathrm{mM}$. The medium was inoculated with a bacterial inoculum deriving from the growth in DSMZ $\mathrm{n}^{\circ} 925$ of a single colony picked from an agarized plate, and performed at an optical density at $600 \mathrm{~nm}$ (SpectroStar Nano, BMG Labtech, Ortenberg, Germany) of 0.05 units of absorbance and incubated at $28 \pm 1{ }^{\circ} \mathrm{C}$ on an orbital shaker at $250 \mathrm{rpm}$ in the dark for 7 days. The $\mathrm{pH}$ dependent growth tests were performed as previously described at decreasing $\mathrm{pH}$ values starting from 10.2, $\mathrm{pH}$ value of the DSMZ $n^{\circ} 925$ medium, down to 7.3. The $\mathrm{pH}$ was corrected by sulfuric acid. Bacterial growth in the different growth conditions was periodically quantified measuring the spectrophotometric absorbance of the bacterial suspension at $600 \mathrm{~nm}$.

\subsection{Thioalkalivibrio sp. 10fs10 Hydrogen Sulfide Oxidation Kinetics}

The hydrogen sulfide oxidation kinetics were performed in 2- and 5-L Infors-HT Labfors 5 reactors, Redox and $\mathrm{pH}$ probes were calibrated with reference solutions before autoclaving, while the oxygen electrode was calibrated in complete growth medium and at stable operative conditions (temperature, stirring and gas flows) at $0 \%$ saturation by flushing nitrogen and $100 \%$ by flushing air at 0.25 or $0.09 \mathrm{NL} / \mathrm{min}$ and 1 bar relative pressure. The bacterial biomass for the oxidation test was grown in the 2-L reactor in DSMZ $\mathrm{n}^{\circ} 925$ medium with a starting thiosulfate concentration of $40 \mathrm{mM}$ at $\mathrm{pH} 10$, temperature constantly held at $28^{\circ} \mathrm{C}$, constant stirrer speed at $480 \mathrm{rpm}$, and air flow set to $0.25 \mathrm{NL} / \mathrm{min}$ at constant inlet pressure of 1 bar in the 2-L reactor. After two weeks of pre-growth on thiosulfate, the whole reactor volume was pelleted in a Beckman coulter centrifuge equipped with a jla8.1000 rotor, at $14,000 \mathrm{~g}$ at room temperature for $20 \mathrm{~min}$. The pellet was immediately re-suspended in $20 \mathrm{~mL}$ of DMSZ $\mathrm{n}^{\circ} 925$ medium and used to inoculate the 5-L reactor for sulfide oxidation tests in the same experimental conditions described before, with the exception of the amendment of sodium sulfide as electron donor instead of thiosulfate. Sulfide was amended by adding solid disodium salt in the reaction vessel. Sulfide residual concentration was estimated by Trüpet-Schlegel spectrophotometric method. The inflection of the recoded redox potential curve indicated the drop of sulfide concentration to negligible residual levels, and was selected as a fast method to estimate hydrogen sulfide consumption rate. Increasing amounts of sodium sulfide to the 5-L reactor were performed sequentially: the same amount of the sodium salt was added three consecutive times. Each amendment was performed after complete oxidation of the previous addition. Sets of three additions were performed with an increasing final hydrogen sulfide concentration, ranging from 1 to $2.5 \mathrm{mM}$ HS. Bacterial growth was quantified by the Bradford assay.

\section{Results}

\subsection{Thioalkalivibrio sp. $10 f$ s10 Strain Isolation and Phylogenetic Characterisation}

The opportunity of the isolation of the new strain was envisaged by analysing results of a shot-gun sequencing of the metagenome of the sediments of interest, which showed a non-negligible relative abundance of the genus Thioalkalivibrio (5\%). The enrichment ended up with the isolation of a single strain that, by the sequencing of the partial gene coding for the $16 \mathrm{~S}$ rRNA showed $100 \%$ of homology 
with the full length Thioalkalivibrio sulfidiphilus HL-EbGr7 16S rRNA gene (GenBank Accession number NC_011901).

In Figure 1, the 16S rRNA gene phylogenetic tree and the amino-acidic based MLS tree are shown. The clade containing Thioalkalivibrio sp. $10 \mathrm{fs} 10$ was unmodified in both phylogenetic and MLS tree topologies and indicated that the strain was classified as a Tv. sulfidiphilus species.

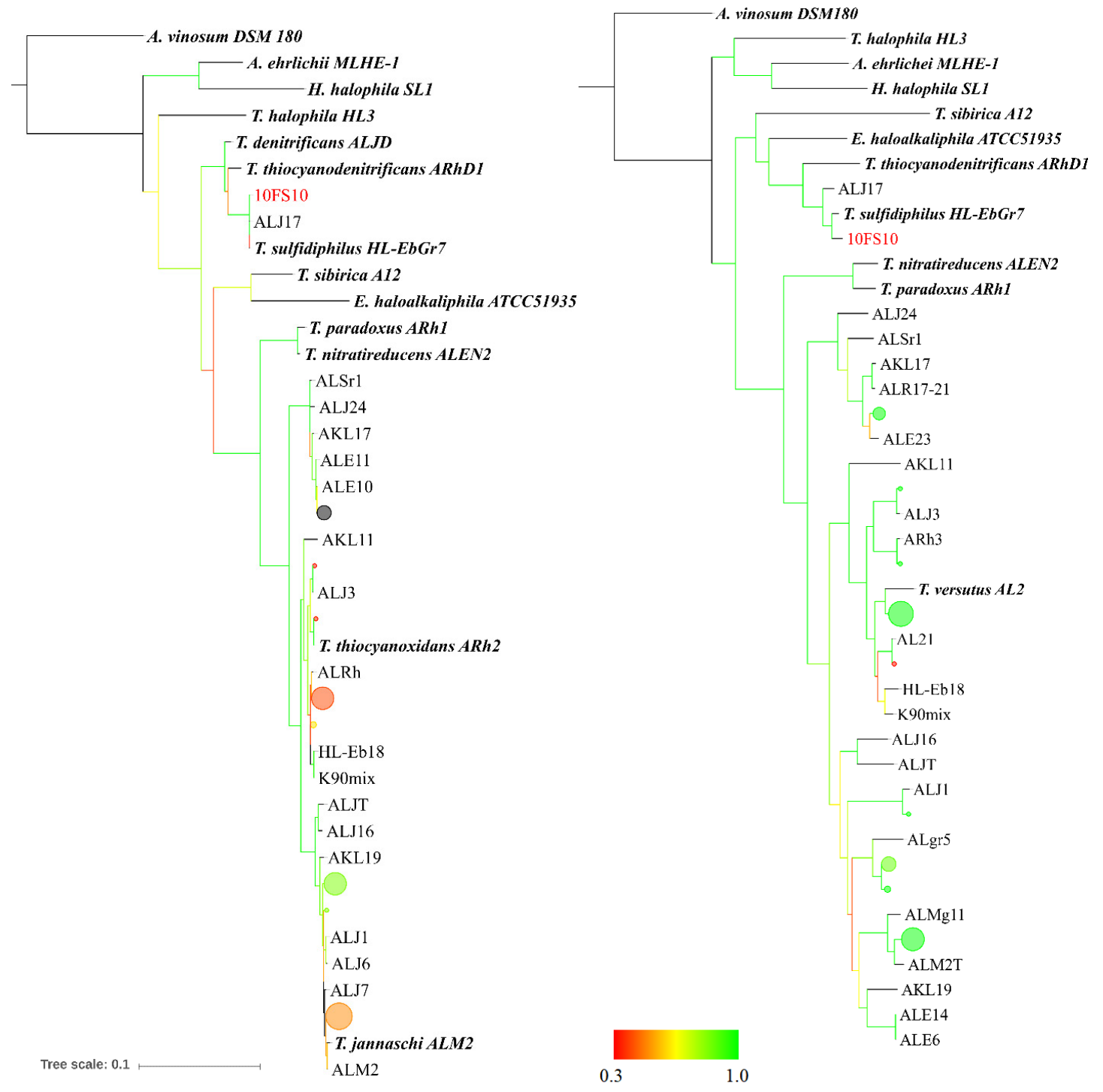

Figure 1. Phylogenetic and multi-locus sequence (MLS) analyses of Thioalkalivibrio spp. Tree on the left: 16S rRNA phylogenetic tree; tree on the right: MLS maximum likelihood tree, based on concatenated amino acid sequences of Clp-DnaJ-GyrA-RpoH-RpoS-SecF. Type strains are in bold. Circles represent collapsed leaves (branch length $<0.001$ for Phylogenetic tree and $<0.05$ for MLS tree): their dimensions are proportional to the number of leaves collapsed. Colour scheme of nodes represents bootstrapping values, as reported in the legend.

The ML phylogenetic tree based on Genome Taxonomy Database entries and classification classified the $10 \mathrm{fs} 10$ as a new strain belonging to the genus Thioalkalivibrio A sulfidiphilus, whose species type-strain is the HL-EbGr7 (Figure 2). 


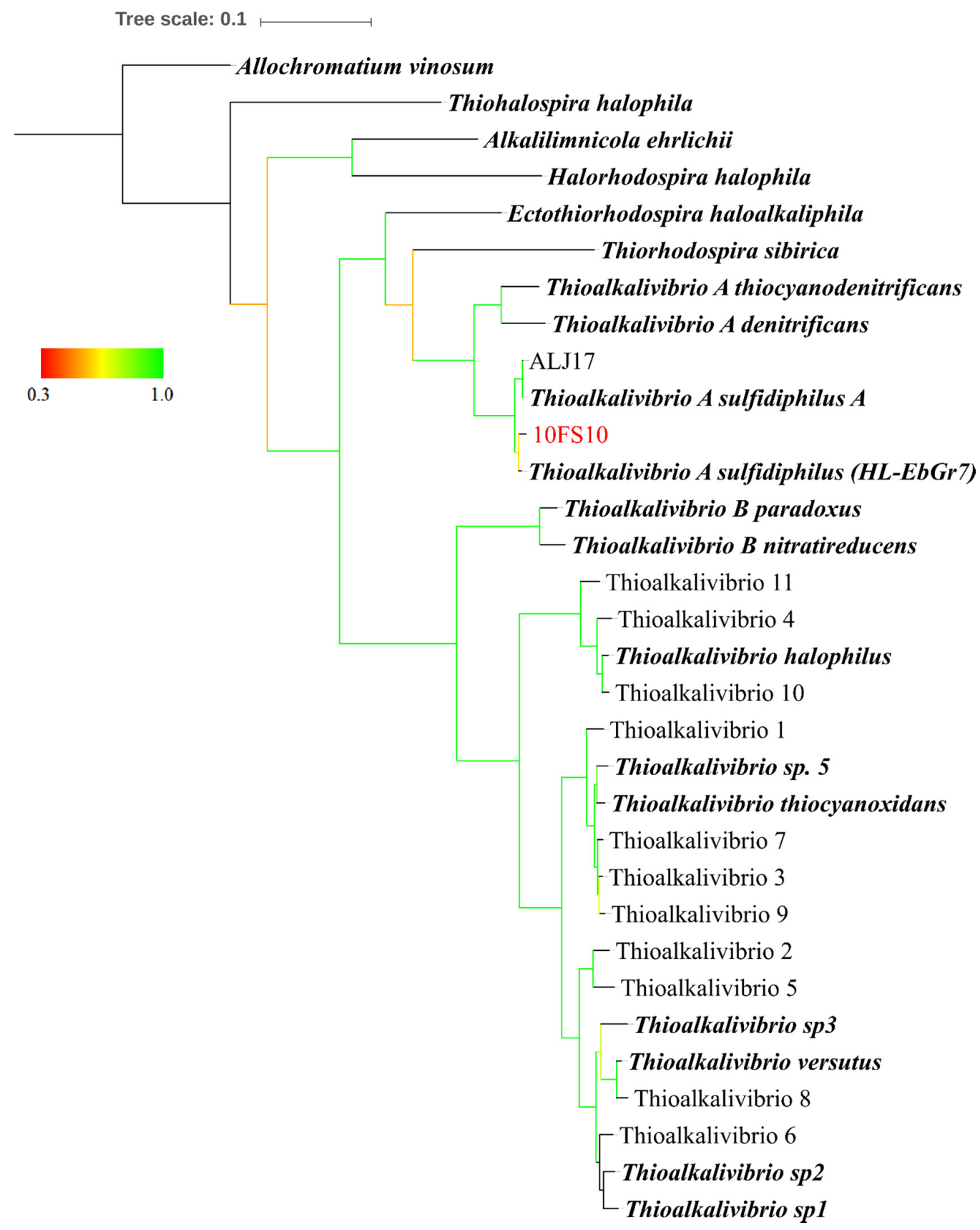

Figure 2. Maximum Likelihood tree performed using masked sequences of 120 housekeeping genes, as suggested by Genome Taxonomy Database criterion of classification, using the Genome Taxonomy Database Toolkit (GTDB-Tk) tool.

The ANI-BBH analysis of the genomes of the two already genome sequenced strains of the Tv. sulfidiphilus species (HL-EbGr7 and ALJ17) and the $10 \mathrm{fs} 10$ isolate, confirms that Thioalkalivibrio sp. 10fs10 shares the same genus of both HL-EbGr7 and ALJ17 strains, but not necessarily the same species (Table 1). Data were partially confirmed by the high taxonomic resolution achieved by dDDH calculation (Table 1), indicating that 10fs10 is a different strain from both Tv. sulfidiphilus HL-EbGr7 and ALJ17, but also suggested that $10 \mathrm{fs} 10$ belongs to a different species with reference to Tv. sulfidiphilus HL-EbGr7, even though with a borderline value (dDDH value 56.8-62.4; $\mathrm{P}_{\mathrm{dDDH}>70 \%}$ 51.07\%). 
Table 1. Average nucleotide identity (ANI) and digital DNA hybridisation (dDDH) calculated for Thioalkalivibrio sp. $10 \mathrm{fs} 10$ and other Tv. sulfidiphilus strains with pairwise ANI-Bidirectional Best Hits (BBH) tool available in IMG and Genome to Genome Distance Calculator (GGDC) v. 2.0 respectively. AF represents the aligned fraction expressed in percentage, ANI 1->2 and ANI 2->1 and related $A F$ values indicate $A N I$ and $A F$ calculation swapping query and reference genomes. $\mathrm{P}_{\mathrm{dDDH}}>70 \%$ and $\mathrm{P}_{\mathrm{dDDH}>79 \%}$ represent false negative probability related to $\mathrm{dDDH}$ calculation. ANI-BBH values comprised between 94 and 96 indicate same genus, while dDDH values comprised between $70 \%$ and $79 \%$ indicate same species.

\begin{tabular}{cccccccc}
\hline Genomes & \multicolumn{3}{c}{ ANI-BBH } & \multicolumn{3}{c}{ dDDH } \\
\hline $\begin{array}{c}\text { Reference genome } \\
\begin{array}{c}\text { Tv. sulfidiphilus } \\
\text { HL-EbGR7 }\end{array}\end{array}$ & ANI 1->2 & ANI 2->1 & AF 1->2 & AF 2->1 & $\begin{array}{c}\text { Estimated DDH } \\
\text { value } \%)\end{array}$ & $\mathrm{P}_{\mathrm{dDDH}>70 \%}$ & $\mathrm{P}_{\mathrm{dDDH}>79 \%}$ \\
$\begin{array}{c}\text { Tv. sulfidiphilus } \\
\text { ALJ17 }\end{array}$ & 94.52 & 95.52 & 78.39 & 80.31 & $56.8-62.4$ & $51.07 \%$ & $12.52 \%$ \\
\hline
\end{tabular}

\subsection{Genome Properties}

Statistics of genome assembly and annotation are reported in Table 2. The draft genome of the isolate $10 \mathrm{fs} 10$ consists of 17 contigs greater than $500 \mathrm{kbp}$, contigs which less than $500 \mathrm{bp}$ in length were discarded. The total length of contigs was $3.42 \mathrm{Mbp}$. A length of $3.16 \mathrm{Mbp}$ characterizes one of that contigs, which cover more than $92 \%$ of the entire genome. The $\mathrm{G}+\mathrm{C}$ percentage determined from the genome sequence is $64.95 \%$. A total of 3243 coding DNA sequences (CDS) were predicted, of which 3175 were annotated as protein coding sequences, while 68 were annotated as RNA genes. A single copy of the genes coding for ribosomal RNA subunits 5S, 16S, and 23S was retrieved. More than $69 \%$ of CDS were assigned to cluster of orthologous-group classification and functional categories (COG).

Table 2. Thioalkalivibrio sp. 10fs10 genome assembly and annotation statistics.

\begin{tabular}{cc}
\hline Genome Properties & Value \\
\hline Total scaffolds & 17 \\
Length & $3.42 \mathrm{Mbp}$ \\
G + C content & $64.95 \%$ \\
Total DNA coding region & 3243 \\
Protein coding region & 3175 \\
rRNA genes & 3 (5S rRNA, 16S rRNA, 23s rRNA) \\
tRNA & 52 \\
tmRNA & 1 \\
Protein coding region with Pfam & 2966 \\
Protein coding region with COG & 2241 \\
Protein coding region with KEGG & 1656 \\
Transmembrane protein coding gene & 781 \\
CRISPR repeats & 2 \\
\hline
\end{tabular}

\subsection{Halo-Alkaline Condition of Growth}

The growth of Thioalkalivibrio sp. $10 \mathrm{fs} 10$ in presence of thiosulfate and increasing $\mathrm{Na}^{+}$concentration was measured. Results obtained (Figure 3) showed that $10 \mathrm{fs} 10$ was capable to grow at a wide interval of $\mathrm{Na}^{+}$concentrations with an optimal growth at $750 \mathrm{mM}$ total $\mathrm{Na}^{+}$content. The $10 \mathrm{fs} 10$ isolate can grow up to $1.5 \mathrm{M} \mathrm{Na}^{+}$concentration. 


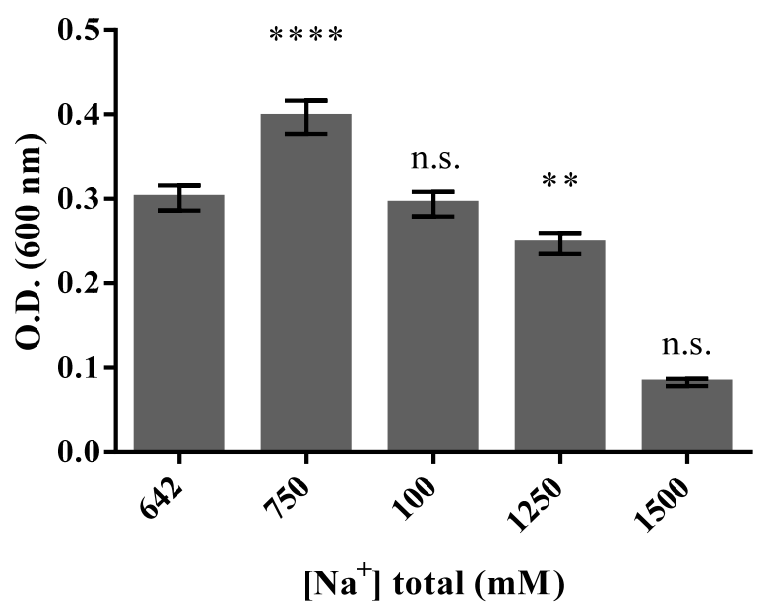

Figure 3. Thioalkalivibrio sp. isolate $10 \mathrm{fs} 10$ growth after 7 days of incubation at increasing sodium concentrations: maintenance medium (DSMZ 925 with $40 \mathrm{mM}$ thiosulfate and nitrate $5 \mathrm{mM}$, pH10) was added with $\mathrm{NaCl}$ at the total sodium concentration reported. Error bars represent SD of 6 replicates. Asterisks indicate significance level at $99 \%\left(^{* *}\right)$, and $99.99 \%\left(^{* * * *}\right)$. n.s—statistically not significant.

The growth of Thioalkalivibrio sp. $10 \mathrm{fs} 10$ at different $\mathrm{pH}$ is reported in Figure 4 . The best growth performances were achieved in the $\mathrm{pH}$ range of 10.2-9.02, however the strain can growth also at neutral $\mathrm{pH}$.

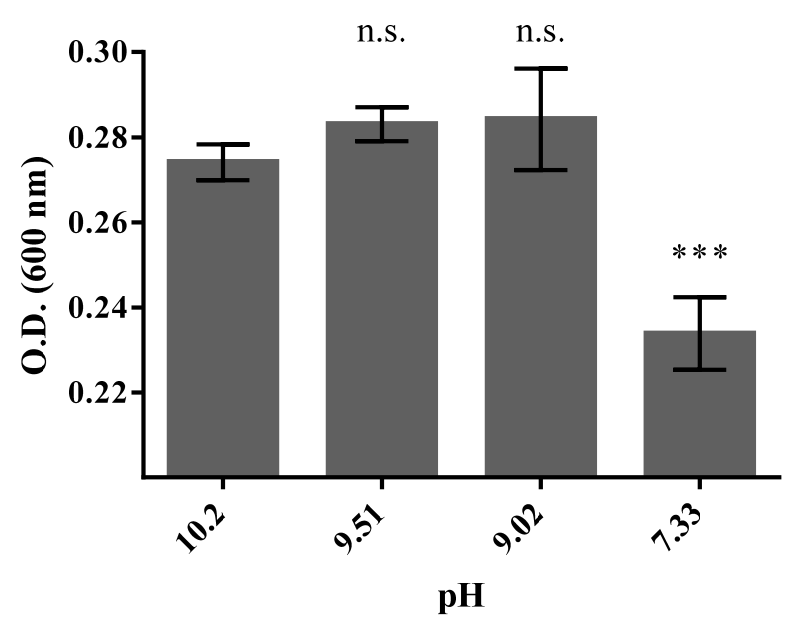

Figure 4. Thioalkalivibrio sp. $10 \mathrm{fs} 10$ growth after 7 days at different $\mathrm{pH}$ : maintenance medium (DSMZ 925 with $40 \mathrm{mM}$ thiosulfate and nitrate $5 \mathrm{mM}$ ) was adjusted at reported $\mathrm{pH}$ by addition of sulfuric acid. Error bars represent SD of 6 replicates. Asterisks indicate significance level at $99.9 \%\left(^{* * *}\right)$. n.s-statistically not significant.

\subsection{Thioalkalivibrio sp. $10 f$ s10 Capacity of Hydrogen Sulfide Oxidation in Halo-Alkaline Growth Conditions}

Bench scale fed-batch experiments of sulfide oxidation in alkaline conditions ( $\mathrm{pH} 10)$ were performed to estimate the hydrogen sulfide oxidation rate of the $10 \mathrm{fs} 10$ isolate. The Haldane inhibition model was adopted to interpolate the specific data points of hydrogen sulfide oxidation rate with reference to the initial sulfide concentration added $\left(\left(\mathrm{HS}^{-}\right)_{\text {init }}\right)$ and to evaluate the kinetics parameters maximum specific oxidation rate $\left(\mathrm{V}_{\max }\right)$, Michaelis-Menten constant $\left(\mathrm{K}_{\mathrm{M}}\right)$ and Haldane inhibition constant (Ki). Results obtained showed that Thioalkalivibrio sp. $10 \mathrm{fs} 10$ oxidized hydrogen sulfide to an optimal concentration of $4 \mathrm{mM}$ with an air flow of $0.25 \mathrm{NL} / \mathrm{min}$, as shown in Figure 5 and Table 3. 


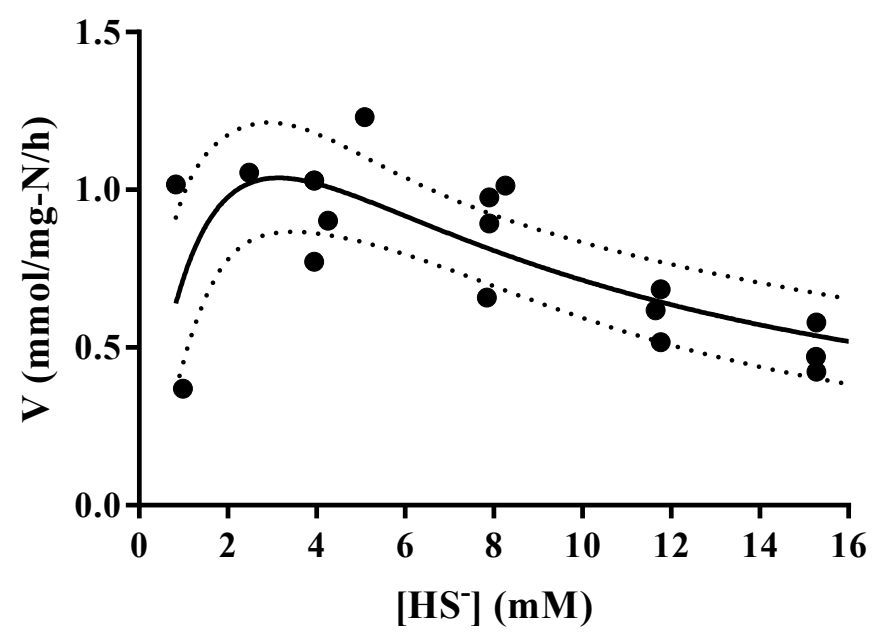

Figure 5. Oxidation performances of Thioalkalivibrio sp. isolate $10 \mathrm{fs} 10 \mathrm{in}$ fed batch reactor for a range of sulfide initial concentrations $1-15 \mathrm{mM}$ with an air flushing at $0.25 \mathrm{NL} / \mathrm{min}$ : graph reports specific oxidation rate of sulfide (i.e., normalized for biomass concentration) against initial sulfide concentration. Continuous line represents Haldane inhibition model applied to substrate. Dashed lines represent 95\% confidence interval of the interpolation.

Table 3. Haldane kinetic parameters for sulfide oxidation tests at diverse air flows.

\begin{tabular}{ccc}
\hline Air Flow & $\mathbf{0 . 2 5} \mathbf{~ N L} / \mathbf{m i n}$ & $\mathbf{0 . 0 9} \mathbf{~ N L} / \mathbf{m i n}$ \\
\hline Vmax $(\mathrm{mmol} / \mathrm{mg}-\mathrm{N} / \mathrm{h})$ & 2.648 & 0.745 \\
$\mathrm{~K}_{\mathrm{M}}(\mathrm{mM})$ & 2.438 & 4.547 \\
$\mathrm{~K}_{\mathrm{i}}(\mathrm{mM})$ & 4.053 & 3.491 \\
\hline
\end{tabular}

Reduced air flow $(0.09 \mathrm{NL} / \mathrm{min}$ of air) was tested to check the variation in specific oxidation rate in growth conditions described as favouring the production of elemental sulfur [13]. Results are shown in Figure 6 and Table 3.

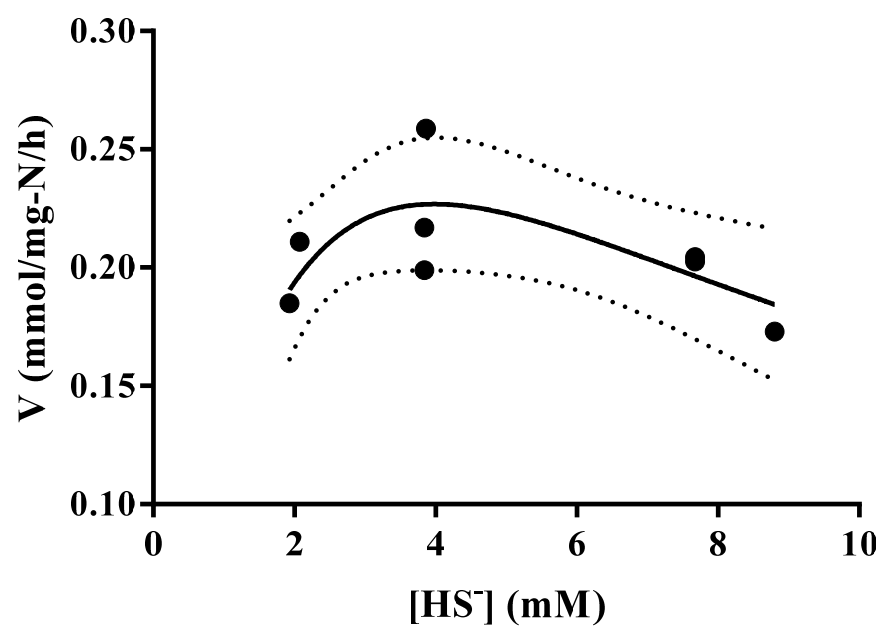

Figure 6. Oxidation performances of Thioalkalivibrio sp. isolate $10 \mathrm{fs} 10 \mathrm{in}$ fed batch reactor for a range of sulfide initial concentrations $1 \mathrm{mM}$ to $10 \mathrm{mM}$ with an air flushing at $0.09 \mathrm{NL} / \mathrm{min}$ : graph reports specific oxidation rate of sulfide (i.e., normalized for biomass concentration) against initial sulfide concentration. Continuous line represents Haldane inhibition model applied to substrate. Dashed lines represent $95 \%$ confidence interval of the interpolation.

Inhibition constants were similar in high and low airflow tests, showing that Thioalkalivibrio sp. $10 \mathrm{fs} 10$ efficiently oxidizes sulfur also in microoxic conditions. Affinity for substrate increases with 
oxygen flow, in fact the $\mathrm{K}_{\mathrm{M}}$ decreases from 4.55 to $2.44 \mathrm{mM}$ when air flow is increased from 0.09 to $0.25 \mathrm{NL} / \mathrm{min}$. Lower sulfide affinity in poorly oxygenated medium is associated to a reduced specific oxidation rate and it is reasonable to assess that elemental sulfur, instead of sulfate, is produced as suggested by the whitish colour of the growth medium (data not shown).

In Table 4, the comparison of two oxidation processes of the same starting sulfide and biomass content, performed at high and low oxygen flows is reported: the $\mathrm{pH}$ drop, due to the oxidation of elemental sulfur to sulfate with the generation of two acidic equivalents, is significant in high oxygen flow conditions.

Table 4. Comparison of low air flow and high air flow oxidations for the same starting hydrogen sulfide and similar biomass concentration.

\begin{tabular}{ccc}
\hline Parameters & $\begin{array}{c}\text { Low Air Flow } \\
\mathbf{( 0 . 0 1 8 ~ N L / m i n )}\end{array}$ & $\begin{array}{c}\text { High Air Flow } \\
\mathbf{( 0 . 2 5} \mathbf{~ N L} / \mathbf{m i n})\end{array}$ \\
\hline (HS') initial $(\mathrm{mM})_{\mathrm{V} \text { ox }}$ spec (mmol/(mg-N·h) & 5.21 & 6 \\
Biomass (mg-N/L) & 0.057 & 0.318 \\
$\Delta \mathrm{pH}$ & 7.31 & 6.51 \\
Elemental sulfur & Negligible & -0.1 \\
\hline
\end{tabular}

\subsection{Thioalkalivibrio sp. $10 f s 10$ Genome Sequencing and Annotation}

Table 5 reports the list of the genes and complete operons implied in sulfur oxidation that could be retrieved in Thioalkalivibrio sp. $10 f s 10$ genome. The Kelly-Friedrich pathway for sulfur oxidation [25,26] relies on a periplasmatic complex composed by four proteins SoxXA, SoxB, SoxYX, and SoxCD that catalyse thiosulfate disproportion to sulfate and elemental sulfur, and sulfide oxidation to sulfate. In microorganisms able to store sulfur in elemental form, the hemomolibdoprotein SoxCD is absent. Thioalkalivibrio sp. $10 \mathrm{fs} 10$ has one copy of $\operatorname{sox} \mathrm{B}$, three copies of $\operatorname{sox} \mathrm{A}$ and $\operatorname{sox} \mathrm{X}$, and two copies of $\operatorname{sox} \mathrm{Y}$ and soxZ. Genes coding for SoxCD are absent.

Table 5. Comparison of gene copy numbers related to genes implied in sulfur metabolism between $T v$. 10fs10, Tv. sulfidiphilus Hl-EbGr7 ${ }^{\mathrm{T}}$, and Tv. sulfidiphilus ALJ17.

\begin{tabular}{|c|c|c|c|}
\hline Gene & $10 \mathrm{fs} 10$ & HL-EbGr7 & ALJ17 \\
\hline soxA & 3 & 4 & 4 \\
\hline $\operatorname{sox} \mathrm{X}$ & 3 & 4 & 4 \\
\hline $\operatorname{sox} \mathrm{Y}$ & 2 & 1 & not found \\
\hline soxZ & 2 & 1 & 1 \\
\hline $\operatorname{sox} \mathrm{B}$ & 1 & 1 & 1 \\
\hline soxC & 0 & 0 & 0 \\
\hline sox $\mathrm{D}$ & 0 & 0 & 0 \\
\hline$f c c \mathrm{~A}$ & 1 & 3 & 2 \\
\hline$f_{c c} \mathrm{~B}$ & 1 & 3 & 2 \\
\hline$d s r \mathrm{~A}$ & 1 & 1 & 1 \\
\hline$d s r \mathrm{~B}$ & 1 & 1 & 1 \\
\hline$d s r C$ & 1 & 1 & 1 \\
\hline aprA & 1 & 1 & 1 \\
\hline apr B & 1 & 1 & 1 \\
\hline sat & 2 & 1 & 1 \\
\hline$h d r \mathrm{~A}$ & 1 & 1 & 1 \\
\hline$h d r \mathrm{~B}$ & 2 & 1 & 1 \\
\hline$h d r C$ & 2 & 1 & 1 \\
\hline sor A & 1 & 1 & 1 \\
\hline sor B & 1 & 1 & 1 \\
\hline
\end{tabular}


A putative second mechanism for sulfide oxidation to elemental sulfur, up to now described only in vitro, is performed by the Flavocytochrome-C dependent oxidase complex (FccAB) [27]. Thioalkalivibrio sp. $10 \mathrm{fs} 10$ has one copy of $f c c \mathrm{AB}$.

The cytoplasmatic Dissimilatory Sulfite Reductase complex, which, in sulfur oxidizers, runs in reverse (rDSR), is involved in further oxidation of elemental sulfur to sulfite [28]. The mechanism of oxidation involves an intracellular cascade of carrier proteins (Rhd, TusA, DsrEFH, DsrC, and the membrane bound DsrE2A) [29] transporting sulfur moiety to the active site of the cytosolic enzyme Sulfite Reductase [30,31], codified by the $d s r$ AABB operon coding for the rDSR complex. The membrane-bound DsrMKJOP electron-transporting complex [32,33] might be involved in the transport of electrons to the iron-sulfur flavoprotein DsrL, with the concomitant reduction of NAD ${ }^{+}$[34]. Thioalkalivibrio sp. 10fs10 has a single copy of all the genes implied in transcription of the aforementioned proteins. A second pathway for elemental sulfur oxidation retrieved in $10 \mathrm{fs} 10$ was the Hetero Disulfide Reductase complex (HDR) based on a gene operon, $h d r \mathrm{ABB}_{1} \mathrm{CC}_{1}$, recently described by [35] for its involvement in the sulfur oxidation pathway.

Further oxidation of sulfite to sulfate within the genus Thioalkalivibrio can be performed by two pathways: a direct oxidation, and an indirect oxidation pathway, carried out with the intermediate Adenosine $5^{\prime}$-Phosphosulfate (APS). Direct oxidation is performed by the heterodimeric sulfite oxidase enzyme SorAB, consisting of a subunit containing a molybdopyranopterin cofactor (SorA) and cytochrome c 552 type with a single heme prosthetic group (SorB) [36]. The indirect pathway is performed by the AprABM complex, docked to the cytoplasmic membrane by the electron-channeling subunit AprM that transfers electrons in the quinone pool [37]. This complex performs the first sulfurylation step of adenosine monophosphate by the docked heterodimeric enzyme APS reductase (AprBA) [38]. Subsequent phosphorylation of APS is performed by ATP sulfurylase (Sat), with the concomitant production of ATP [39]. Thioalkalivibrio sp. 10fs10 has genes for both the direct and indirect sulfite oxidation to sulfate.

The results of the genomic annotation of Thioalkalivibrio sp. 10fs10, referred to the genes and complete operons codifying for proteins and enzymes implied in osmotic stress and high $\mathrm{pH}$ adaptation are listed in Supplementary Table S1.

In Thioalkalivibrio sp. 10fs10, the genes coding for the primary osmoprotectant glycine/betaine synthesis by glycine poly-methylation have been retrieved. The genes involved in the synthesis of secondary osmoprotectants, sucrose, and sucrose phosphate, have been also recovered.

The genes involved in the synthesis of the highly unsaturated, non-polar membrane lipid squalene, by non-mevalonate pathway, putatively involved in the decrease of the membrane permeability to the migration of ions into the cell [39], have been retrieved, as well as the genes for the synthesis of cardiolipin. Cardiolipin synthesis is supposed to improve the efficiency of proton capture through the membrane [40], to stabilize the respiratory complex in alkaline conditions [41], and to improve the Cytochrome-C scavenging effect of reactive oxygen species [42].

About primary and secondary ion pumps for osmoregulation, the genes encoding for sodium/proton translocation machinery have been retrieved. More in details, Thioalkalivibrio sp. $10 \mathrm{fs} 10$ harbours one nuoABCDEFGHIJKLMN complete operon for proton extruding machinery, one $\mathrm{Na}^{+} / \mathrm{H}^{+}$multi-subunit antiporter coded by the mrp operon (mrpABCDEFG) and two $r n f$ ABCDGE operons coding for a primary sodium or proton extruding pump (NADH or ferredoxin dependent). Moreover, the $n h a \mathrm{D}$ gene codifying for a single unit sodium/proton antiporter, described for its efficiency at alkaline $\mathrm{pH}(\mathrm{pH}>8)[43]$ was also retrieved.

\section{Discussion}

The shot-gun sequencing of the metagenome of the contaminated sediments here in study, showed a non-negligible relative abundance of the genus Thioalkalivibrio, suggesting an ecological role of the latter in the sediments. Thioalkalivibrio in brackish environments was already reported as the result of the screening of clone libraries from metagenomic extracts or deep sequencing of metagenomes. 
However, any ecological role has been already suggested in environments very diverse from those associated to halo-alkaline soda lakes, characterized by very high $\mathrm{pH}$ and salinity. All the already described strains are involved in the sulfur cycle in those extreme environments, but the sediments here analysed were characterized by a neutral $\mathrm{pH}$ and a sodium concentration referable to a brackish environment. The further characteristic of the sediments was eventually a significative contamination by petroleum derived hydrocarbons. The quantification of the nutrient concentrations in the sediments indicated a high sulfur concentration, referable to the anoxic nature of the sediments. In the context of the contamination, the presence of plastic metabolic traits of sulfur oxidizing or reducing bacteria might be expected and actually the genus Thioalkalivibrio might have shown a cosmopolitan attitude and eventually a higher flexibility in the adaptation to different growth conditions and propagation than the already described.

The here isolated new strain of the genus Thioalkalivibrio was phylogenetically compared to strains of the same genus, isolated from different soda lakes and treatment plants for $\mathrm{H}_{2} \mathrm{~S}$ containing gas. As reported by [44], the ALJ and ARh strains were isolated from soda lakes in Kenya. The HL-EbGr7 and HL-Eb18 were isolated from full scale sulfide removing bioreactors of Eerbeek (Netherlands). The ALR and ALBR strains were isolated from sulfide oxidising bioreactors inoculated with sediments of Mongolian soda lakes. The ALE strains were isolated from Wadi Natrum Lake (Egypt), the ALM strain was isolated from Mongolian soda lakes, and the AKL strain and K90mix were isolated from a soda lake in Russia.

Both phylogenetic and MLS tree topologies suggested that the $10 \mathrm{fs} 10$ belongs to the Tv. sulfidiphilus species. The ANI-BBH analysis confirmed that $10 \mathrm{fs} 10$ belongs to the genus Thioalkalivibrio and the high taxonomic resolution achieved by $\mathrm{dDDH}$ calculation, indicated that $10 \mathrm{fs} 10$ is a new strain in the genus when compared to already isolated and sequenced strains HL-EbGr7 and ALJ17 of the sulfidifilus species. On Genome Taxonomy Database [45] several bacteria and archaea were reclassified on the base of genomic comparison and results here obtained confirmed the classification of $10 \mathrm{fs} 10$ as a new strain belonging to the genus sulfidiphilus.

In relation to the putative participation of the strain to the sulfur cycle in the sediments, the $10 \mathrm{fs} 10$ genome annotation suggested a metabolic plasticity of the strain with reference to the capability to grow in environments characterized by changes in the redox potential. Thioalkalivibrio sp. $10 \mathrm{fs} 10$ efficiently oxidizes sulfur in microoxic conditions or high redox potential. Affinity for reduced sulfur increases with the increase in the redox potential, showing that Thioalkalivibrio sp. $10 \mathrm{fs} 10$ adopts a more efficient sulfur oxidation metabolism when oxygen availability is higher. In fact, the $10 \mathrm{fs} 10$ genome annotation showed that the strain is capable to catalyse thiosulfate and sulfide oxidation to elemental sulfur in the periplasm, to store elemental sulfur in extracellular compartments and to oxidize these latter to sulfite by both the rDSR and the HDR complexes. Actually, all sequenced genomes of the Thioalkalivibrio spp. harbour the HDR complex [46]. However, the coexistence of the HDR and rDSR complexes was, up to now, restricted to Thioalkalivibrio sulfidiphilus HL-EbGr7, Thioalkalivibrio sulfidiphilus ALJ17, Thioalkalivibrio nitratireducens ALJD, Thioalkalivibrio AKL19, and Thioalkalivibrio ALE19. Moreover, the 10fs10 genome annotation indicated that the strain oxidizes sulfite to sulfate by both direct (SorAB) and indirect (Apr/Sat) oxidations. In this context, it is worth mentioning that, as suggested also by other authors [47], the rDSR/SorAB pathway might be related to sulfur oxidation carried out at high redox potentials, while the HDR/Apr/Sat pathway might be related to low redox potentials. Moreover, the coexistence of two distinct pathways for sulfur accumulation in its elemental form, starting from both highly reduced sulfide or poorly reduced thiosulfate, suggests that Thioalkalivibrio sp. $10 \mathrm{fs} 10$ is suited to face shortage of reduced sulfur forms.

The plasticity in the sulfur metabolism associated to the above described genome organisation, might be the signature for a high plasticity and adaptability of the genus Thioalkalivibrio to the environment, higher than the already described, and the $10 \mathrm{fs} 10$ strain might be one representative of the not yet described adaptability. In fact, as here described, the $10 \mathrm{fs} 10$ strain showed a higher flexibility with reference to halo-alkaline conditions of growth, when compared to the type strain of 
the species, the HL-EbGr7. The 10fs10 genome annotation showed a duplication of the rnfABCDGE operon coding for a putative primary sodium or proton extruding pump, retrieved in single copy in HL-EbGr7. Actually, by inspection of the halo-alkaliphilic Thioalkalivibrio sp. genomes deposited on IMG (study name: Genome sequencing of 100 strains of the halo-alkaliphilic chemolithoautotrophic sulfur-oxidizing bacterium Thioalkalivibrio), the duplication of the Rnf complex can be found in only Thioalkalivibrio paradoxus Arh1 and Thioalkalivibrio versutus AL2. The duplication of $r n f$ gene cluster is a quite rare feature [48] retrieved in few microorganisms characterized by high metabolic plasticity [49] and nitrogen fixation capabilities [50]. A clear participation of the cluster to the adaptation to the halo-alkaline conditions of growth is not already demonstrated, however, an Rnf complex variant in the alkalitolerant Acetobacterium woodi was shown to have an essential role in homeostasis [51,52].

On the other hand, the $10 \mathrm{fs} 10$ genome annotation indicated that the strain shows very similar features to the Thioalkalivibrio genus in terms of genetic arrangement for adaptation to $\mathrm{pH}$ variation and osmotic stress, harbouring genes for the synthesis of osmolyte such as glycine/betaine and sucrose [53] and for highly unsaturated, non-polar lipids like squalene, synthetized for reinforcing the structure of the cell membrane to withstand osmotic pressure [47,53,54]. Moreover, in $10 f s 10$ and in the Thioalkalivibrio genus, the genes for the cardiolipin synthesis have been retrieved. Cardiolipin is supposed to improve efficiency of proton capture through the membrane [40], to stabilize the respiratory complex in alkaline conditions [41] and to improve the Cytochrome-C scavenging effect of reactive oxygen species [42]. On the other hand, it is worth mentioning that $10 \mathrm{fs} 10$ harbours the $n h a \mathrm{D}$ gene, coding for a single unit sodium/proton antiporter, characterized by a high efficiency at alkaline $\mathrm{pH}$ that has never been retrieved in any of the genomes of the strains already sequenced in the genus Thioalkalivibrio.

\section{Conclusions}

A new isolate of the Thioalkalivibrio sulfidiphilus sp. that, with reference the type strain of the species, the HL-EbGr7, shows a higher capacity to adapt to $\mathrm{pH}$ variation of the growth environment, was isolated from brackish sediments contaminated by petroleum derived hydrocarbons. Even though Thioalkalivibrio sp. $10 \mathrm{fs} 10$ shows very similar features to Tv sulfidiphilus HL-EbGr7 in terms of genetic arrangement for sulfur oxidation and accumulation, the higher flexibility of the new strain with reference to halo-alkaline condition of growth might be related to a different organization of the genome. In fact, the duplication of an operon encoding for a putative primary sodium or proton extruding pump was retrieved in 10fs10 and not in HL-EbGr7. Moreover, the presence of a sodium/proton antiporters, with alkaline-adapted capabilities was recorder in $10 \mathrm{fs} 10$ and, up to now, not retrieved in the Thioalkalivibrio genus. The metabolic flexibility of the bacterial species in relation to the redox potential and the capability to utilize reduced sulfur as electron source was successfully exploited in fed batch and continuous reactor scale processes, where the maximal specific oxidation rate for reduced sulfur obtained for $10 \mathrm{fs} 10$ in low air flow tests, reached values very similar to the one observed in previously described operational conditions [11]. At increasing air flows, Thioalkalivibrio sp. 10fs10, increased the specific oxidation rate of about five times, resulting to be an interesting candidate for the development of bio-based processes dedicated to the control of $\mathrm{H}_{2} \mathrm{~S}$ emissions.

Supplementary Materials: The following are available online at http://www.mdpi.com/2073-4441/12/5/1385/s1, Table S1: Genes involved in bacterial homeostasis in saline and alkaline environments annotated in Thioalkalivibrio sp. $10 \mathrm{fs} 10$ genome. IMG-ER and Rast identifiers are reported.

Author Contributions: Conceptualization, S.B. and S.D.G.; methodology, S.B., S.D.G., S.L.C.; software, S.B., S.D.G., S.L.C., A.L., A.P., D.P.; validation, S.B., S.D.G.; formal analysis, S.B., S.D.G., S.L.C., A.L., A.P.; investigation, S.B., S.D.G.; resources, S.D.G.; data curation, S.B., S.L.C., A.L., A.P., D.P., G.P. and S.D.G.; writing-original draft preparation, S.B. and S.D.G.; writing-review and editing, S.B. and S.D.G.; visualization, S.B. and S.D.G.; supervision, S.D.G.; project administration, G.P.; funding acquisition, S.D.G. All authors have read and agreed to the published version of the manuscript.

Funding: This work was financed by the Department of Biology, University of Pisa, and BD Biodigressioni srl, Pisa, Italy. Alla Lapidus and Andrey Prijibelski were supported by St. Petersburg University (ID 51555639). 
Acknowledgments: We thank Michele Castelli, Department of Bioscience, University of Milan, Italy for phylogenomics suggestions.

Conflicts of Interest: The authors declare that the research was conducted in the absence of any commercial or financial relationships that could be interpreted as a potential conflict of interest.

\section{References}

1. Becarelli, S.; Chicca, I.; Siracusa, G.; La China, S.; Gentini, A.; Lorenzi, R.; Munz, G.; Petroni, G.; Levin, D.B.; Di Gregorio, S. Hydrocarbonoclastic Ascomycetes to enhance co-composting of total petroleum hydrocarbon (TPH) contaminated dredged sediments and lignocellulosic matrices. N. Biotechnol. 2019, 50, 27-36. [CrossRef]

2. Di Gregorio, S.; Gentini, A.; Siracusa, G.; Becarelli, S.; Azaizeh, H.; Lorenzi, R. Phytoremediation for improving the quality of effluents from a conventional tannery wastewater treatment plant. Int. J. Environ. Sci. Technol. 2015, 12, 1387-1400. [CrossRef]

3. Di Gregorio, S.; Siracusa, G.; Becarelli, S.; Mariotti, L.; Gentini, A.; Lorenzi, R. Isolation and characterization of a hydrocarbonoclastic bacterial enrichment from total petroleum hydrocarbon contaminated sediments: Potential candidates for bioaugmentation in bio-based processes. Environ. Sci. Pollut. Res. 2016, 23, 87-94. [CrossRef] [PubMed]

4. Lampis, S.; Ferrari, A.; Cunha-Queda, A.C.; Alvarenga, P.; Di Gregorio, S.; Vallini, G. Selenite resistant rhizobacteria stimulate $\mathrm{SeO}(3)$ (2-) phytoextraction by Brassica juncea in bioaugmented water-filtering artificial beds. Environ. Sci. Pollut. Res. Int. 2009, 16, 663-670. [CrossRef] [PubMed]

5. Sorokin, D.Y.; Banciu, H.L.; Muyzer, G. Functional microbiology of soda lakes. Curr. Opin. Microbiol. 2015, 25, 88-96. [CrossRef]

6. Mu, T.; Zhou, J.; Yang, M.; Xing, J. Complete genome sequence of Thialkalivibrio versutus D301 isolated from Soda Lake in northern China, a typical strain with great ability to oxidize sulfide. J. Biotechnol. 2016, 227, 21-22. [CrossRef]

7. Lee, Y.M.; Hahm, D.; Jung, Y.-J.; Park, S.H.; Chun, J.; Hong, S.G. Bacterial community of sediments from the Australian-Antarctic ridge. Polar Biol. 2014, 37, 587-593. [CrossRef]

8. Cao, H.; Wang, Y.; Lee, O.O.; Zeng, X.; Shao, Z.; Qian, P.Y. Microbial sulfur cycle in two hydrothermal chimneys on the Southwest Indian Ridge. MBio 2014, 5, e00980-13. [CrossRef]

9. $\quad$ Liang, J.B.; Chen, Y.Q.; Lan, C.Y.; Tam, N.F.Y.; Zan, Q.J.; Huang, L.N. Recovery of novel bacterial diversity from mangrove sediment. Mar. Biol. 2007, 150, 739-747. [CrossRef]

10. Sundarakrishnan, B.; Pushpanathan, M.; Jayashree, S.; Rajendhran, J.; Sakthivel, N.; Jayachandran, S.; Gunasekaran, P. Assessment of microbial richness in pelagic sediment of Andaman Sea by bacterial tag encoded FLX titanium amplicon pyrosequencing (bTEFAP). Indian J. Microbiol. 2012, 52, 544-550. [CrossRef]

11. Zhang, Z.; Lo, I.M.C.; Yan, D.Y.S. An integrated bioremediation process for petroleum hydrocarbons removal and odor mitigation from contaminated marine sediment. Water Res. 2015, 83, 21-30. [CrossRef] [PubMed]

12. Sorokin, D.Y.; van den Bosch, P.L.F.; Abbas, B.; Janssen, A.J.H.; Muyzer, G. Microbiological analysis of the population of extremely haloalkaliphilic sulfur-oxidizing bacteria dominating in lab-scale sulfide-removing bioreactors. Appl. Microbiol. Biotechnol. 2008, 80, 965-975. [CrossRef] [PubMed]

13. Van den Bosch, P.L. Biological Sulfide Oxidation by Natron-Alkaliphilic Bacteria: Application in Gas Desulfurization. Doctoral Dissertation, Wageningen Universiteit, Wageningen, The Netherlands, 2008.

14. de Graaff, M.; Klok, J.B.M.; Bijmans, M.F.M.; Muyzer, G.; Janssen, A.J.H. Application of a 2-step process for the biological treatment of sulfidic spent caustics. Water Res. 2012, 46, 723-730. [CrossRef] [PubMed]

15. Smet, E.; Lens, P.; Van Langenhove, H. Treatment of waste gases contaminated with odorous sulfur compounds. Crit. Rev. Environ. Sci. Technol. 1998, 28, 89-117. [CrossRef]

16. Weisburg, W.G.; Barns, S.M.; Pelletier, D.A.; Lane, D.J. $16 \mathrm{~S}$ ribosomal DNA amplification for phylogenetic study. J. Bacteriol. 1991, 173, 697-703. [CrossRef] [PubMed]

17. Dombek, P.E.; Johnson, L.K.; Zimmerley, S.T.; Sadowsky, M.J. Use of repetitive DNA sequences and the PCR to differentiate Escherichia coli isolates from human and animal sources. Appl. Environ. Microbiol. 2000, 66, 2572-2577. [CrossRef]

18. Versalovic, J.; Koeuth, T.; Lupski, J.R. Distribution of repetitive DNA sequences in eubacteria and application to fingerprinting of bacterial genomes. Nucleic Acids Res. 1991, 19, 6823-6831. [CrossRef] 
19. Edgar, R.C. MUSCLE: Multiple sequence alignment with high accuracy and high throughput. Nucleic Acids Res. 2004, 32, 1792-1797. [CrossRef]

20. Tamura, K.; Nei, M. Estimation of the number of nucleotide substitutions in the control region of mitochondrial DNA in humans and chimpanzees. Mol. Biol. Evol. 1993, 10, 512-526. [CrossRef]

21. Whelan, S.; Goldman, N. A general empirical model of protein evolution derived from multiple protein Families Using a Maximum-Likelihood Approach. Mol. Biol. Evol. 2001, 18, 691-699. [CrossRef]

22. Varghese, N.J.; Mukherjee, S.; Ivanova, N.; Konstantinidis, K.T.; Mavrommatis, K.; Kyrpides, N.C.; Pati, A. Microbial species delineation using whole genome sequences. Nucleic Acids Res. 2015, 43, 6761-6771. [CrossRef] [PubMed]

23. Meier-Kolthoff, J.P.; Auch, A.F.; Klenk, H.-P.; Göker, M. Genome sequence-based species delimitation with confidence intervals and improved distance functions. BMC Bioinform. 2013, 14, 60. [CrossRef]

24. Auch, A.F.; von Jan, M.; Klenk, H.-P.; Göker, M. Digital DNA-DNA hybridization for microbial species delineation by means of genome-to-genome sequence comparison. Stand Genom. Sci. 2010, 2, 117-134. [CrossRef] [PubMed]

25. Appia-Ayme, C.; Little, P.J.; Matsumoto, Y.; Leech, A.P.; Berks, B.C. Cytochrome Complex Essential for Photosynthetic Oxidation of both Thiosulfate and Sulfide in Rhodovulum sulfidophilum. J. Bacteriol. 2001, 183, 6107-6118. [CrossRef]

26. Friedrich, C.G.; Rother, D.; Bardischewsky, F.; Quentmeier, A.; Fischer, J. Oxidation of Reduced Inorganic Sulfur Compounds by Bacteria: Emergence of a Common Mechanism? Appl. Environ. Microbiol. 2001, 67, 2873-2882. [CrossRef] [PubMed]

27. Bosshard, H.R.; Davidson, M.W.; Knaff, D.B.; Millett, F. Complex formation and electron transfer between mitochondrial cytochrome $\mathrm{c}$ and flavocytochrome c552 from Chromatium vinosum. J. Biol. Chem. 1986, 261, 190-193. [PubMed]

28. Beller, H.R.; Chain, P.S.G.; Letain, T.E.; Chakicherla, A.; Larimer, F.W.; Richardson, P.M.; Coleman, M.A.; Wood, A.P.; Kelly, D.P. The Genome Sequence of the Obligately Chemolithoautotrophic, Facultatively Anaerobic Bacterium Thiobacillus denitrificans. J. Bacteriol. 2006, 188, 1473-1488. [CrossRef] [PubMed]

29. Stockdreher, Y.; Venceslau, S.S.; Josten, M.; Sahl, H.G.; Pereira, I.A.C.; Dahl, C. Cytoplasmic sulfurtransferases in the purple sulfur bacterium Allochromatium vinosum: Evidence for sulfur transfer from DsrEFH to DsrC. PLoS ONE 2012, 7, e40785. [CrossRef]

30. Cort, J.R.; Selan, U.; Schulte, A.; Grimm, F.; Kennedy, M.A.; Dahl, C. Allochromatium vinosum DsrC: Solution-state NMR structure, redox properties, and interaction with DsrEFH, a protein essential for purple sulfur bacterial sulfur oxidation. J. Mol. Biol. 2008, 382, 692-707. [CrossRef]

31. Dahl, C. Sulfur metabolism in phototrophic bacteria. In Mod. Top. Phototrophic Prokaryotes; Springer International Publishing: Cham, Switzerland, 2017; pp. 27-66. [CrossRef]

32. Grein, F.; Pereira, I.A.C.; Dahl, C. Biochemical characterization of individual components of the Allochromatium vinosum DsrMKJOP transmembrane complex aids understanding of complex function in vivo. J. Bacteriol. 2010, 192, 6369-6377. [CrossRef]

33. Sander, J.; Engels-Schwarzlose, S.; Dahl, C. Importance of the DsrMKJOP complex for sulfur oxidation in Allochromatium vinosum and phylogenetic analysis of related complexes in other prokaryotes. Arch. Microbiol. 2006, 186, 357-366. [CrossRef] [PubMed]

34. Lübbe, Y.J.; Youn, H.-S.; Timkovich, R.; Dahl, C. Siro(haem)amide in Allochromatium vinosum and relevance of DsrL and DsrN, a homolog of cobyrinic acid a,c-diamide synthase, for sulfur oxidation. FEMS Microbiol. Lett. 2006, 261, 194-202. [CrossRef] [PubMed]

35. Koch, T.; Dahl, C. A novel bacterial sulfur oxidation pathway provides a new link between the cycles of organic and inorganic sulfur compounds. ISME J. 2018, 12, 2479-2491. [CrossRef]

36. Kappler, U. Bacterial sulfite-oxidizing enzymes. Biochim. Biophys. Acta Bioenerg. 2011, 1807, 1-10. [CrossRef] [PubMed]

37. Meyer, B.; Kuever, J. Molecular analysis of the distribution and phylogeny of dissimilatory adenosine-5' -phosphosulfate reductase-encoding genes (aprBA) among sulfur-oxidizing prokaryotes. Microbiology 2007, 153, 3478-3498. [CrossRef] [PubMed]

38. Dahl, C. Insertional gene inactivation in a phototrophic sulfur bacterium: APS-reductase-deficient mutants of Chromatium vinosum. Microbiology 1996, 142, 3363-3372. [CrossRef] 
39. Parey, K.; Demmer, U.; Warkentin, E.; Wynen, A.; Ermler, U.; Dahl, C. Structural, biochemical and genetic characterization of dissimilatory ATP sulfurylase from Allochromatium vinosum. PLoS ONE 2013, 8, e74707. [CrossRef]

40. Brändén, M.; Sanden, T.; Brzezinski, P.; Widengren, J. Localized proton microcircuits at the biological membrane-water interface. Proc. Natl. Acad. Sci. USA 2006, 103, 19766-19770. [CrossRef]

41. Haines, T.H.; Dencher, N.A. Cardiolipin: A proton trap for oxidative phosphorylation. FEBS Lett. 2002, 528, 35-39. [CrossRef]

42. Ascenzi, P.; Coletta, M.; Wilson, M.T.; Fiorucci, L.; Marino, M.; Polticelli, F.; Sinibaldi, F.; Santucci, R. Cardiolipin-cytochrome c complex: Switching cytochrome c from an electron-transfer shuttle to a myoglobinand a peroxidase-like heme-protein. IUBMB Life 2015, 67, 98-109. [CrossRef]

43. Liu, J.; Xue, Y.; Wang, Q.; Wei, Y.; Swartz, T.H.; Hicks, D.B.; Ito, M.; Ma, Y.; Krulwich, T.A. The activity profile of the NhaD-type $\mathrm{Na}^{+}\left(\mathrm{Li}^{+}\right) / \mathrm{H}^{+}$antiporter from the soda lake haloalkaliphile Alkalimonas amylolytica is adaptive for the extreme environment. J. Bacteriol. 2005, 187, 7589-7595. [CrossRef] [PubMed]

44. Ahn, A.C.; Meier-Kolthoff, J.P.; Overmars, L.; Richter, M.; Woyke, T.; Sorokin, D.Y.; Muyzer, G. Genomic diversity within the haloalkaliphilic genus Thioalkalivibrio. PLoS ONE 2017, 12, e0173517. [CrossRef] [PubMed]

45. Parks, D.H.; Chuvochina, M.; Waite, D.W.; Rinke, C.; Skarshewski, A.; Chaumeil, P.A.; Hugenholtz, P. A standardized bacterial taxonomy based on genome phylogeny substantially revises the tree of life. Nat. Biotechnol. 2018, 36, 996-1004. [CrossRef] [PubMed]

46. Berben, T.; Overmars, L.; Sorokin, D.Y.; Muyzer, G. Diversity and distribution of sulfur oxidation-related genes in Thioalkalivibrio, a genus of chemolithoautotrophic and haloalkaliphilic sulfur-oxidizing bacteria. Front. Microbiol. 2019, 10, 160. [CrossRef] [PubMed]

47. Muyzer, G.; Sorokin, D.Y.; Mavromatis, K.; Lapidus, A.; Foster, B.; Sun, H.; Ivanova, N.; Pati, A.; D’haeseleer, P.; Woyke, T.; et al. Complete genome sequence of Thioalkalivibrio sp. K90mix. Stand Genom. Sci. 2011, 5, 341-355. [CrossRef] [PubMed]

48. Biegel, E.; Schmidt, S.; González, J.M.; Müller, V. Biochemistry, evolution and physiological function of the Rnf complex, a novel ion-motive electron transport complex in prokaryotes. Cell Mol. Life Sci. 2011, 68, 613-634. [CrossRef]

49. Strittmatter, A.W.; Liesegang, H.; Rabus, R.; Decker, I.; Amann, J.; Andres, S.; Henne, A.; Fricke, W.F.; Martinez-Arias, R.; Bartels, D.; et al. Genome sequence of Desulfobacterium autotrophicum HRM2, a marine sulfate reducer oxidizing organic carbon completely to carbon dioxide. Environ. Microbiol. 2009, 11,1038-1055. [CrossRef]

50. Curatti, L.; Brown, C.S.; Ludden, P.W.; Rubio, L.M. Genes required for rapid expression of nitrogenase activity in Azotobacter vinelandii. PNAS 2005, 102, 6291-6296. [CrossRef]

51. Müller, V.; Aufurth, S.; Rahlfs, S. The $\mathrm{Na}^{+}$cycle in Acetobacterium woodii: Identification and characterization of a $\mathrm{Na}^{+}$translocating F1F0-ATPase with a mixed oligomer of 8 and $16 \mathrm{kDa}$ proteolipids. Biochim. Biophys. Acta Bioenerg. 2001, 1505, 108-120. [CrossRef]

52. Westphal, L.; Wiechmann, A.; Baker, J.; Minton, N.P.; Müller, V. The Rnf complex is an energy-coupled transhydrogenase essential to reversibly link cellular NADH and ferredoxin pools in the acetogen Acetobacterium woodii. J. Bacteriol. 2018, 200, e00357-18. [CrossRef]

53. Banciu, H.; Sorokin, D.Y.; Kleerebezem, R.; Muyzer, G.; Galinski, E.A.; Kuenen, J.G. Growth kinetics of haloalkaliphilic, sulfur-oxidizing bacterium Thioalkalivibrio versutus strain ALJ 15 in continuous culture. Extremophiles 2004, 8, 185-192. [CrossRef] [PubMed]

54. Muyzer, G.; Sorokin, D.Y.; Mavromatis, K.; Lapidus, A.; Clum, A.; Ivanova, N.; Pati, A.; d'Haeseleer, P.; Woyke, T.; Kyrpides, N.C. Complete genome sequence of Thioalkalivibrio sulfidophilus HL-EbGr7. Stand Genom. Sci. 2011, 4, 23-35. [CrossRef] [PubMed]

(C) 2020 by the authors. Licensee MDPI, Basel, Switzerland. This article is an open access article distributed under the terms and conditions of the Creative Commons Attribution (CC BY) license (http://creativecommons.org/licenses/by/4.0/). 